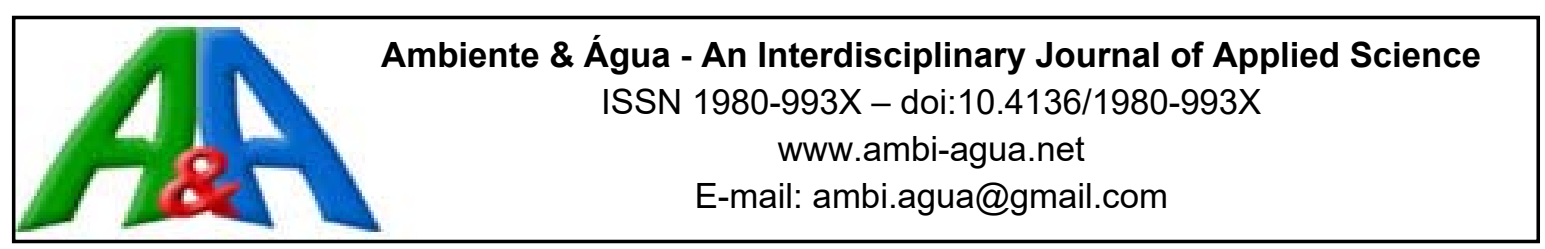

\title{
Metal pollution assessment in a Brazilian hydroelectric reservoir: Geophagus brasiliensis as a suitable bioindicator organism
}

\author{
doi:10.4136/ambi-agua.2061
}

Received: 02 Dec. 2016; Accepted: 08 May 2017

\author{
Halina Binde Doria ${ }^{1 *}$; Carmen Lúcia Voigt ${ }^{2}$; \\ Sandro Xavier de Campos ${ }^{2}$; Marco Antonio Ferreira Randi ${ }^{1}$ \\ ${ }^{1}$ Universidade Federal do Paraná (UFPR), Curitiba, PR, Brasil \\ Departamento de Biologia Celular e Molecular \\ ${ }^{2}$ Universidade Estadual de Ponta Grossa (UEPG), Ponta Grossa, PR, Brasil \\ Departamento de Química \\ "Corresponding author: e-mail: halinaplant@gmail.com, \\ clvoigt@uepg.br, campos@uepg.br, mafrandi@ufpr.br
}

\begin{abstract}
Vossoroca is a reservoir in the Brazilian state of Paraná. Although it is located near big cities and can be used as a human water supply, it has remained unstudied. Concentrations of toxic metals and arsenic in sediments, water, liver, gills, and muscle of Geophagus brasiliensis from the reservoir were analyzed using atomic absorption spectrometry. Histological analyses were performed on the gills and the livers using scanning electron microscopy and light microscopy, respectively. The results showed that Vossoroca sediments were moderately polluted by copper, chromium, nickel and arsenic. Cadmium was above legal limits in the water. Histopathological assessment revealed epithelial alterations in the secondary lamella to be the most common abnormality observed in the gills and necrosis, melanomacrophage centers in the livers. In conclusion, although the reservoir is located in an Environmental Protection Area, it is negatively affected by human activity. Further, Geophagus brasiliensis was a suitable bioindicator for metal pollution studies.
\end{abstract}

Keywords: freshwater fish, reservoir, toxic metals.

\section{Avaliação da poluição por metais em um reservatório hidroelétrico brasileiro: Geophagus brasiliensis como adequado organismo bioindicador}

\section{RESUMO}

Vossoroca é um reservatório localizado no estado Paraná - Brasil. Embora esteja próximo de grandes cidades e possa ser usado para abastecimento de água para população humana, ele permaneceu sem ser estudado. As concentrações de metais tóxicos e arsênico nos sedimentos, água, fígado, brânquias e músculo de Geophagus brasiliensis do reservatório foram analisadas por espectrometria de absorção atômica. As análises histológicas foram realizadas em brânquia e fígado por microscopia eletrônica de varredura e microscopia de luz, respectivamente. Os resultados mostraram que os sedimentos de Vossoroca estão moderadamente poluídos pelo cobre, cromo, níquel e arsênico. O cádmio estava acima dos limites legais na água. A avaliação 
histopatológica revelou alterações epiteliais na lamela secundária como a anormalidade mais comum observada nas brânquias, e necrose e centros melanomacrófagos, no fígado. Em conclusão, O Geophagus brasiliensis é um bioindicador adequado para estudos de poluição de metais. Embora o reservatório esteja localizado em uma Área de Proteção Ambiental, ele é afetado negativamente pela atividade humana.

Palavras-chave: peixe dulcícola, metais tóxicos, reservatório.

\section{INTRODUCTION}

Due to the increase in environmental awareness seen in Brazil and around the world in recent decades, water consumption has become a major societal concern. Because of the desire to improve water quality both to protect aquatic life and to make water available for humans, knowledge of how reservoirs are impaired by human pollution is not only necessary, but vital. The study area of this work is known in Brazil as the Vossoroca Reservoir. It was created in 1949 in Paraná State, Brazil for hydroelectric purposes (IAP, 2009). However, the local human population continues to grow, and with it, the demand for potable water. Thus, the Sanitation Company of Paraná State (SANEPAR) has begun searching for alternative reservoirs for the public water supply (Brembatti, 2014). Because the Vossoroca Reservoir is $50 \mathrm{~km}$ away from the capital city, Curitiba, and is near to other cities in the greater Curitiba area, it can be easily converted into a public water supply reservoir.

Metals are considered potentially hazardous and toxic. They tend to accumulate rapidly in the environment and can reach toxic levels in short periods. Arsenic, cadmium, chromium, copper, lead, nickel and zinc are the most common toxic metals found in water and can trigger adverse biological effects in the biota through redox-cycling reactions and free radical generation or bonding to sulfhydryl and thiol groups of proteins (Beijer and Jernelov, 1986; Jaishankar et al., 2104; Valko et al., 2005). Due to human activity, metal bioavailability in the environment has increased to alarming levels (Castro-González and Méndez-Armenta, 2008).

When assessing aquatic environmental metal pollution, chemical analyses of metal concentrations cannot provide sufficient information because they cannot describe the true availability or even the adverse effects of metal mixtures in aquatic organisms (Maceda-Veiga et al., 2012). Therefore, fish are often used as bioindicators because they are considered sensitive; their life cycles are exclusively aquatic and bioaccumulation processes are easily detectable (Blanco et al., 2014; Lowe-McConnell, 1999; Mazzoni and Iglesias-Rios, 2002). Geophagus brasiliensis, a fish native to South America, has been found to be sensitive to environmental stressors and has been used as a bioindicator in several field studies (Benincá et al., 2012; Clemente et al., 2010; Osório et al., 2013; Paraguassú et al., 2005; Ruas et al., 2008; Wilhelm Filho et al., 2001), but its sensitivity to different metals has not yet been evaluated. In order to detect disturbances and evaluate both fish health and symptoms of environmental health, histopathological analyses serve as a biomarker that can show the cumulative effects of pollution on organisms chronically exposed ( $\mathrm{Au}, 2004)$.

Though government monitoring programs for water quality control exist for several Brazilian reservoirs (IAP, 2009), there is little information available on the contaminants in the water, sediment, or fish in these water bodies. For this reason, the objectives of this study were to provide critical information on metal pollution levels in Vossoroca and to evaluate Geophagus brasiliensis as a bioindicator species in cases of metal pollution. To achieve this objective, current heavy metal contamination levels in the sediment and water of the reservoir were investigated, and a histopathological examination was performed on the liver and gills of a native fish species (Geophagus brasiliensis) that is chronically exposed to these waters. The

Rev. Ambient. Água vol. 12 n. 4 Taubaté - Jul. / Aug. 2017 
metals considered in the analysis were copper $(\mathrm{Cu})$, manganese $(\mathrm{Mn})$, zinc $(\mathrm{Zn})$, cobalt $(\mathrm{Co})$, cadmium $(\mathrm{Cd})$, chromium $(\mathrm{Cr})$, silver $(\mathrm{Ag})$, lead $(\mathrm{Pb})$, nickel $(\mathrm{Ni})$, aluminum $(\mathrm{Al})$, and arsenic (As). The results of this study offer unprecedented data on the Vossoroca Reservoir, as well as critical information on the bioindicator species, Geophagus brasiliensis.

\section{MATERIALS AND METHODS}

\subsection{Study area and bioindicator organism}

The study area is known as the Vossoroca Reservoir. It is part of the upper portion of the São João Basin and is formed as the result of a dam on the São João River. The reservoir is in the city of Tijucas do Sul in Paraná State, Brazil and it is inside the Environmental Protection Area (EPA) of Guaratuba (IAP, 2009). Its geographical coordinates are $25^{\circ} 52^{\prime} \mathrm{S} / 49^{\circ} 00^{\prime} \mathrm{W}$ (Figure 1). It covers an area of $5.1 \mathrm{~km}^{2}$ and has an average depth of $8 \mathrm{~m}$ and maximum depth of 17 m (IAP, 2009). Additionally, a highway (BR-376) linking southwestern Brazil and southern Brazil crosses the reservoir, bringing with it intense traffic that includes many trucks. This activity is a potential source of pollutants and creates the risk of toxic substance spills. Because it is considered a small reservoir, an area next to the road that cuts through the reservoir and that is thought to be the main source of water contamination by toxic metals was chosen for the data collection and is identified as VOS in Figure 1.
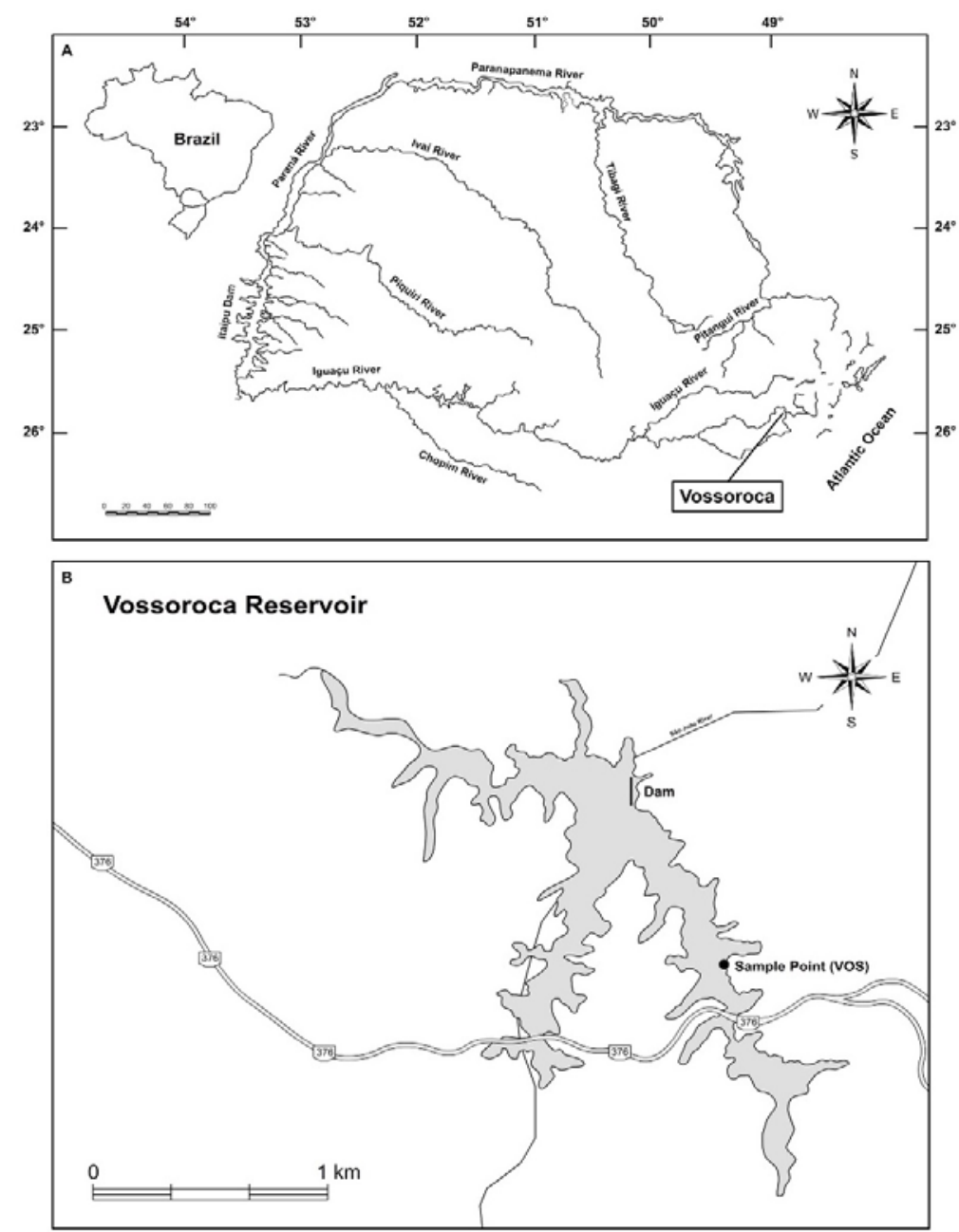

Figure 1. Locations of the Vossoroca Reservoir in the state of Paraná, Brazil; VOS - the sample site of the study. 
The fish used as a bioindicator organism in this study was Geophagus brasiliensis (Perciformes, Cichlidae). It is one of the most abundant species in lentic aquatic ecosystems. It has omnivore benthopelagic habits, which recruits both bioavailable metals into the water column and in the sediment (Hauser-Davis et al., 2010) and has the key characteristics of an ideal bioindicator (Li et al., 2010; Mazzoni and Iglesias-Rios, 2002; Paraguassú et al., 2005).

\subsection{Experimental design}

Twenty-eight $G$. brasiliensis specimens were captured with cast nets and were anesthetized with MS-222 $\left(1 \mathrm{~g} \mathrm{~L}^{-1}\right)$ and euthanized by spinal cord section. Average weight and average total length of the fish were found to be $23 \mathrm{~g}$ and $11.40 \mathrm{~cm}$, respectively. For the histopathological analysis, the second right gill arch and a liver fragment were sampled. Muscle, liver and gill samples were stored at $-80^{\circ} \mathrm{C}$. All applicable international, national, and/or institutional guidelines for the care and use of animals were followed. Water and sediment samples were collected in triplicate according to the United States Environmental Protection Agency (USEPA, 2001) and were kept frozen at $-20^{\circ} \mathrm{C}$.

\subsection{Chemical analysis}

Acid digestion for water, sediments and tissues samples were performed according to USEPA (1992; 1996). Arsenic levels were determined using an atomic absorption spectrometer (Varian ${ }^{\circledR}$, AA 240Z) with electro thermal atomization in a graphite oven (model GTA 120) equipped with a transverse Zeeman corrector for background correction. A hollow cathode lamp was used for the procedure. In addition, argon was used as inert carrying gas with a $0.3 \mathrm{~L} \mathrm{~min}^{-1}$ flow. Pyrolytically-coated graphite tubes were used in all of the procedures.

The concentrations of the remaining metals were determined using a flame atomic absorption spectrometer (Varian ${ }^{\circledR}$, AA $240 \mathrm{FS}$ ) equipped with multi-element hollow cathode lamps, and with a deuterium lamp as a background corrector. In the case of Al, the flame used was a nitrous oxide acetylene flame with a flow of $10.24 \mathrm{~L} \mathrm{~min}^{-1}$ for the Al flame and of $6.95 \mathrm{~L} \mathrm{~min}^{-1}$ for the air oxidant acetylene flame. When the other metals were analyzed, the flame used was an air oxidant acetylene flame with a flow of $13.5 \mathrm{~L} \mathrm{~min}^{-1}$ for the air and of

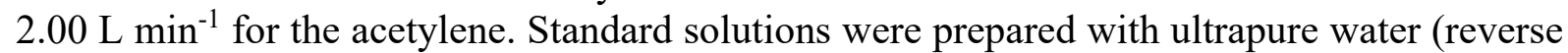
osmosis and a Gehaka ${ }^{\circledR}$ water filter), and the stock solutions were prepared with $1000 \mathrm{mg} \mathrm{L}^{-1}$ Qhemis High Purity ${ }^{\circledR}$ metals. The analytical curve was derived from these standards.

The bioconcentration factor (BCF) is the result of absorption, distribution and elimination of substances after an organism's exposure to contaminated water (Van Leeuwen and Vermeire, 2007). In the current study, this ratio was calculated using the metal found in the fish tissue and was expressed as $\mu \mathrm{g} \mathrm{g}^{-1}$ dry weight, divided by the metal found in the water, expressed as $\mu \mathrm{g}$ $\mathrm{mL}^{-1}$. The bioaccumulation factor (BAF) is used to determine the tendency of a given compound or element to accumulate in an organism as a result of its exposure to food or sediment (Van Leeuwen and Vermeire, 2007). This ratio was calculated using the concentration of metals found in the fish tissue divided by the concentration of metals found in the sediment, both of which were expressed as $\mu \mathrm{g} \mathrm{g}^{-1}$ (Lau et al., 1998).

\subsection{Histopathology}

Liver samples were preserved in FAA fixative (ethanol $80 \%$, formaldehyde $40 \%$, and glacial acetic acid 5\%) for 16 hours. After dehydration with a graded ethanol series, the samples were purified in xylene and embedded in Paraplast-Plus resin (Sigma). Sections were cut to 3$5 \mu \mathrm{m}$ in length, prepared in a Leica RM2145 microtome, and stained with hematoxilin and eosin/floxin. The second right gill arch was fixed in a Karnovsky solution (glutaraldehyde $2.5 \%$; paraformaldehyde $4 \%$ and cacodylate buffer $0.1 \mathrm{M}$ ) at $4^{\circ} \mathrm{C}$. The tissue was dehydrated 
with an ethanol series before critical point drying was applied using liquid $\mathrm{CO} 2$. The dried tissue was metalized with gold and examined under a JEOL JSM-6360LV scanning electron microscope. Histopathological assessment in liver and gills were performed by examination of lesions described by Bernet et al. (1999) and were expressed in relative frequencies.

\section{RESULTS AND DISCUSSION}

\subsection{Vossoroca sediments are moderately polluted by metals and arsenic}

Concentrations of the metals and of arsenic measured in the sediments are provided in Table 1. Aluminum exhibited the highest concentration, followed by $\mathrm{Mn}>\mathrm{Zn}>\mathrm{Cr}>\mathrm{Cu}>\mathrm{Ni}>$ $\mathrm{Co}>\mathrm{Pb}>\mathrm{Ag}>\mathrm{As}>\mathrm{Cd}$. Bioavailability of the metals revealed the following decreasing order of metal concentrations: $\mathrm{Al}>\mathrm{Mn}>\mathrm{Cr}>\mathrm{Co} \sim \mathrm{Cu}>\mathrm{Pb}>\mathrm{Zn}>\mathrm{Ni}>\mathrm{Ag}>\mathrm{Cd}>\mathrm{As}$.

Four of the eleven metals analyzed herein - $\mathrm{Cr}, \mathrm{Cu}, \mathrm{Ni}$ and $\mathrm{Cd}-$ and $\mathrm{As}$ are present in Vossoroca Reservoir above national or international limits (CONAMA, 2012; CEQG 2014; MacDonald et al., 2000; Thomas, 1987). As metal distribution in sediments provides a record of the spatial and temporal pollution history of an ecosystem (Alloway, 2013), this signifies that, although the reservoir is inside the Guaratuba EPA, it has been suffering from the consequences of human activity for a considerable amount of time.

The Al element was the most abundant metal in sediments, but was not found in either the water samples or any fish tissues. This is likely due to the physicochemical parameters of the water such as the near-neutral $\mathrm{pH}$ (Camargo et al., 2009). Metals in sediments are being continually made bioavailable to and are in constant exchange with the water column; thus, concentration levels in the two compartments vary significantly (Camargo et al., 2009; Ferreira et al., 2010).

Table 1. Analysis of metal and arsenic concentrations in sediments, water, and fish tissues.

\begin{tabular}{|c|c|c|c|c|c|c|}
\hline \multicolumn{3}{|c|}{ Sediments } & \multirow{2}{*}{$\begin{array}{c}\text { Water } \\
\text { Total } \\
\end{array}$} & \multicolumn{3}{|c|}{ Fish Tissues } \\
\hline & Bioavailable & Total & & Liver & Gills & Muscle \\
\hline $\mathrm{Cu}$ & $1.68 \pm 0.08$ & $28.85 \pm 0.61$ & $0.0034 \pm 0.0002$ & $28.44 \pm 1.05$ & $3.65 \pm 0.61$ & $14.09 \pm 0.53$ \\
\hline Mn & $21.03 \pm 0.46$ & $267.08 \pm 0.52$ & $0.0093 \pm 0.0002$ & $18.61 \pm 0.86$ & $34.22 \pm 2.46$ & $13.18 \pm 1.07$ \\
\hline $\mathrm{Zn}$ & $1.06 \pm 0.07$ & $51.89 \pm 1.11$ & $0.0035 \pm 0.0002$ & $45.63 \pm 0.59$ & $24.90 \pm 1.45$ & $16.82 \pm 0.78$ \\
\hline $\mathrm{Co}$ & $1.69 \pm 0.11$ & $19.77 \pm 0.84$ & $0.0020 \pm 0.0001$ & $*$ & $*$ & * \\
\hline $\mathrm{Cd}$ & $0.025 \pm 0.01$ & $1.91 \pm 0.05$ & $0.0014 \pm 0.0001$ & $*$ & $*$ & $*$ \\
\hline $\mathrm{Cr}$ & $2.71 \pm 0.04$ & $34.04 \pm 0.55$ & $0.0162 \pm 0.0004$ & $*$ & $*$ & $*$ \\
\hline $\mathrm{Ag}$ & $0.52 \pm 0.09$ & $4.30 \pm 0.42$ & $0.0057 \pm 0.0001$ & $14.32 \pm 0.72$ & $17.48 \pm 1.36$ & $4.51 \pm 0.41$ \\
\hline $\mathrm{Pb}$ & $1.52 \pm 0.08$ & $19.44 \pm 1.27$ & $*$ & $11.42 \pm 0.42$ & $4.63 \pm 0.48$ & $1.65 \pm 0.12$ \\
\hline $\mathrm{Ni}$ & $0.69 \pm 0.02$ & $23.20 \pm 0.75$ & $0.0058 \pm 0.0004$ & $9.93 \pm 0.33$ & $6.61 \pm 0.34$ & $2.78 \pm 0.32$ \\
\hline $\mathrm{Al}$ & $68427.35 \pm 104$ & $713.95 \pm 63.90$ & $*$ & $*$ & $*$ & $*$ \\
\hline As & $0.14 \pm 0.002$ & $3.91 \pm 0.05$ & $*$ & $1.19 \pm 0.02$ & $0.55 \pm 0.03$ & $*$ \\
\hline
\end{tabular}

Note: Sediment and fish tissue results are expressed as $\mathrm{mg} / \mathrm{kg}$ dry weight; water results are expressed as $\mathrm{mg} / \mathrm{L}$. All values are expressed as means \pm standard error of the mean.

* indicates a result below method's detection limit.

\subsection{G. brasiliensis may be able to decrease the residual time of $\mathbf{C d}$ in tissues}

Water from Vossoroca Reservoir had an average $\mathrm{pH}$ of 6.7. Concentrations of metals and arsenic in water samples and metal accumulation in Geophagus brasiliensis tissue samples are presented in Table 1. In water, $\mathrm{Cr}$ had the highest concentration, followed by

\section{IPABH}


$\mathrm{Mn}>\mathrm{Ni}>\mathrm{Ag}>\mathrm{Zn}>\mathrm{Cu}>\mathrm{Co}>\mathrm{Cd}$. $\mathrm{Cd}$ and $\mathrm{Cr}$ were neither bioaccumulated nor bioconcentrated in any of the tissues extracted from G. brasiliensis.

Cd concentration was higher than the legal limits (CONAMA 357, 2005), but its presence was not detected in any of the three tissues analyzed. It is known that not all metals taken up by organisms are bioaccumulated; fish can, to a certain degree, regulate metal concentration in tissues (Maceda-Veiga et al., 2012; Pourang et al., 2005), but Cd is one of the most toxic metals, as it is nonessential, and can quickly bioaccumulate in fish (Liu et al., 2011). Even though metallothioneins tend to detoxify nonessential elements (Hansen et al., 2007), their excretion is a slow process (Besirovic et al., 2010). Accordingly, a previous study by Calza et al. (2004) also demonstrated the absence of $\mathrm{Cd}$ accumulation in $G$. brasiliensis tissues. Therefore, the results suggest that $G$. brasiliensis may not bioaccumulate cadmium, thus raising the possibility that it is not a good bioindicator organism for the study of this specific metal.

Similar results were found for $\mathrm{Cr}$, which was the most concentrated metal in the water and which was found above USEPA limits in the sediment; however, it was below detection limits in the fish samples. Nevertheless, unlike $\mathrm{Cd}, \mathrm{Cr}$ is an essential element and is required for the metabolism of sugar and fat (Anderson, 1997; Lall, 2002). Still, both situations provide evidence that measuring metal concentrations either in water or sediment does not provide information on the risk posed by metal bioaccumulation to the biota.

\subsection{Behavioral and dietary habits of $G$. brasiliensis greatly influence the bioaccumulation of metals and metalloids}

Bioaccumulation and bioconcentration factors are shown in Table 2. The liver was found to have greater affinity for metal and arsenic bioconcentration when compared with muscle and gill tissues. A higher BCF and BAF of Mn and Ag was found in the gills. Muscle tissue did not exhibit elevated bioaccumulation of metals when compared with the other tissues analyzed. All metal concentrations in the muscle tissues were below the limits established by Brazilian law (ANVISA, 1965; 1998). However, Pb concentration in the muscle tissues was found to be above the limit established by the European Commission, $-0.5 \mathrm{mg} \mathrm{kg}^{-1}$ dry weight (EC, 2006).

Table 2. Bioconcentration factors (BCF) and bioaccumulation factors (BAF) in G. brasiliensis tissues.

\begin{tabular}{cccccccc}
\hline & \multicolumn{3}{c}{ BCF } & & & BAF & \\
\cline { 1 - 4 } \cline { 1 - 2 } $\mathrm{Cu}$ & Liver & Gills & Muscle & & Liver & Gills & Muscle \\
$\mathrm{yn}$ & 2001.07 & 3679.57 & 1417.20 & & 0.069 & 0.128 & 0.049 \\
$\mathrm{Zn}$ & 13037.14 & 7114.28 & 4805.71 & & 0.879 & 0.479 & 0.324 \\
$\mathrm{Co}$ & 0 & 0 & 0 & & 0 & 0 & 0 \\
$\mathrm{Cd}$ & 0 & 0 & 0 & & 0 & 0 & 0 \\
$\mathrm{Cr}$ & 0 & 0 & 0 & & 0 & 0 & 0 \\
$\mathrm{Ag}$ & 2512.28 & 3066.66 & 791.23 & & 3.330 & 4.065 & 1.049 \\
$\mathrm{~Pb}$ & - & - & - & & 0.587 & 0.238 & 0.085 \\
$\mathrm{Ni}$ & 1712.07 & 1139.65 & 479.31 & & 0.428 & 0.285 & 0.119 \\
$\mathrm{Al}$ & - & - & - & & 0 & 0 & 0 \\
$\mathrm{As}$ & - & - & - & 0.304 & 0.141 & 0 \\
\hline
\end{tabular}

Note: - indicates error when divided by zero. 
$\mathrm{Pb}$ and $\mathrm{As}$ were not detected in the surface waters, but $\mathrm{Pb}$ was found to have bioaccumulated in all three of the tissues analyzed and As was found in the gills and liver of Geophagus brasiliensis. These results are likely a consequence of the fish's behavior. The species is largely dependent on sediments; its feeding habits are based on sediment foraging (Lowe-McConnell, 1999; Mazzoni and Iglesias-Rios, 2002; Moraes et al., 2004) and it has an omnivorous diet that ranges from algae and seeds to small animals such as crustaceans, mollusks, and aquatic insects (Gomiero and Braga, 2008; Moraes et al., 2004). It also builds nests on the slope of the reservoir to protect its offspring (Suzuki and Agostinho, 1997). It is important to emphasize that sediment-associated metals pose a direct risk to detrital and deposit-feeding benthic organisms and may represent long-term sources of contamination in higher trophic levels (Mendil and Uluozlu, 2007). Finally, this result highlights the fact that metals and arsenic can accumulate in fish both through water and through the direct contact of fish with sediments, and emphasizes the difficulty of comparing metal accumulation between the same tissues extracted from different species due to the ecological particularities of each species (Demirak, et al., 2006; Mendil and Uluozlu, 2007).

\subsection{Essential metals involved in detoxification processes were the most bioaccumulated metals}

It is likely that the high degree of bioaccumulation of $\mathrm{Zn}, \mathrm{Mn}$ and $\mathrm{Cu}$ are linked to their intrinsic metabolic roles (Maceda-Veiga et al., 2012). These metals are involved in the functions of several enzymes and are considered essential metals. They are mainly involved the regulation of key enzymatic detoxification processes such as superoxide dismutase and metallothioneins (Agtas et al., 2007).

G. brasiliensis organs expressed affinity for metals at different levels. The liver had the highest metal bioaccumulation of the three tissues analyzed, followed by the gills, which is consistent with other studies on the differences in metal accumulation in fish tissues (Jezierska and Witeska, 2006; Maceda-Veiga et al., 2012; Papagiannis et al., 2004; Pyle et al., 2005; Rashed, 2001; Wei et al., 2014). It also reinforces existing evidence that, because the liver reflects metal bioavailability in both the water and sediments, it is an important target organ for detecting bioaccumulation processes (Jezierska and Witeska, 2006; Karadede et al., 2004).

\subsection{Exposure to toxic metals induced histopathological damages in liver and gills}

Liver histopathology revealed few abnormalities with low relative frequencies (Table 3 and Figure 2 A-D). Necrosis, the most frequent alteration observed in liver, manifests as irreversible tissue lesions that are closely linked to chronic exposure to pollutants, including metals such as $\mathrm{Pb}, \mathrm{Cu}, \mathrm{Mn}$ and Ni (Bernet et al., 1999; Costa et al., 2009; Mela et al., 2013; Rabitto et al., 2005; Van Dyk et al., 2009; Benincá et al., 2010). Cell death associated with this type of injury not only induces an inflammatory response, but also decreases the number of functional cells in the tissue, a process that has deleterious consequences for organ function (Akaishi et al., 2004). Moreover, because MMCs play a role in cleaning and particle elimination and appear to be sites of inflammation (Balamurugan et al., 2012), a high incidence of MMCs, as was observed in this study, may be a sensitive indicator of impaired fish health and stressful environmental conditions (Agius and Roberts, 2003; Balamurugan et al., 2012; Camargo and Martinez, 2007; Hinton et al., 2008). 
Table 3. Frequency of morphological changes observed in liver and gills of Geophagus brasiliensis.

\begin{tabular}{|c|c|c|c|}
\hline \multicolumn{4}{|c|}{ Relative Frequencies (\%) } \\
\hline \multicolumn{2}{|c|}{ Liver } & \multicolumn{2}{|c|}{ Gills } \\
\hline Necrosis & 70 & Epithelial Alteration & 100 \\
\hline MMCs & 60 & Desquamation & 50 \\
\hline Cholestasis & 30 & Necrosis & 25 \\
\hline Infiltration & 20 & Lamellar Fusion & 25 \\
\hline Hemorrhage & 0 & Neoplasia & 12.5 \\
\hline Steatosis & 0 & Hyperplasia & 12.5 \\
\hline Tissue Differentiation & 0 & Aneurysm & 0 \\
\hline Granulomatosis & 0 & Parasites & 0 \\
\hline Necrosis & 70 & Epithelial Alteration & 100 \\
\hline $\mathrm{MMCs}$ & 60 & Desquamation & 50 \\
\hline Cholestasis & 30 & Necrosis & 25 \\
\hline
\end{tabular}
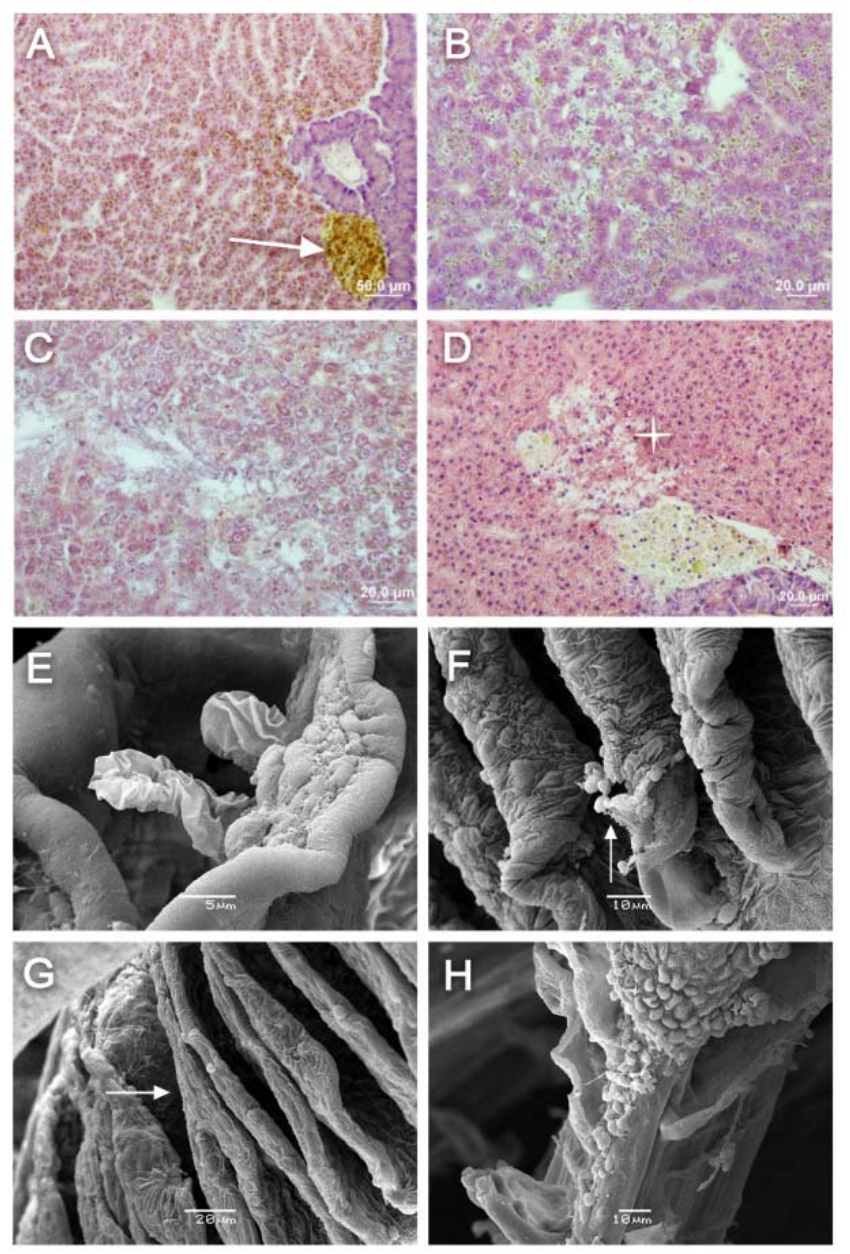

Figure 2. Histopathological alterations found in the liver of Geophagus brasiliensis (A-D); (A) Cholestasis and MMCs (arrow); (B) Cholestasis; (C) Onset of necrosis and cholestasis; (D) Necrotic area (star) and MMCs. Histopathological alterations found in the gills of Geophagus brasiliensis (E$\mathrm{H})$; (E) Cell projections in secondary lamella. (F) Epithelium desquamation in secondary lamella (arrow). (G) Lamellar fusion (arrow). (H) Necrotic area of primary lamella and loss of secondary lamellae. 
Intrahepatic cholestasis was another frequent alteration observed in G. brasiliensis specimens from the Vossoroca Reservoir. The presence of intrahepatic cholestasis is not well understood in aquatic organisms due to the low frequency of its observation in ecotoxicological studies (Safahieh et al., 2011; Wolf and Wolfe, 2005). This situation can cause membrane damage due to detergent action of bile salts; it may lead to cell death either by apoptosis or by necrosis (Biagianti-Risbourg et al., 1998; Jaescheke et al., 2002). Some studies have associated exposure to metals with the onset of cholestasis in the livers of different fish species (Ayas et al., 2007; Jaescheke et al., 2002; Moreira et al., 2014; Safahieh et al., 2011). Therefore, it is possible that the relatively high frequency of necrosis is a result of both direct damage produced by chronic exposure to the metals and indirect damage to the membrane caused by bile salts, with subsequent cell death.

Several morphological alterations were observed in the gills of Geophagus brasiliensis (Figure $2 \mathrm{E}-\mathrm{H}$ ) and are expressed in their relative frequencies in Table 3. The gills are a highly vascularized and the first tissue to contact bioavailable pollutants in water. For these reasons, they are vulnerable to histopathological alterations and may even reflect early deleterious effects of xenobiotics present at low concentrations (Pawert et al., 1998). In the current study, the three most frequent histopathological disturbances observed were epithelial changes in the secondary lamella, desquamation, and necrosis, alterations induced by high concentrations of metals in water (Pandey et al., 2008). These are regressive changes that culminate in the functional impairment of the organ (Bernet et al, 1999; Biagini et al., 2009), directly reflecting physiological difficulties in gas exchange between the gill epithelium and the aquatic environment.

Correspondingly, G. brasiliensis chronic exposed to environments where deleterious anthropogenic activities take place exhibited the same lesions observed in the present work (Benincá et al., 2010; Osório et al., 2013). These changes in liver and gills also show that the species chosen for the study is sensitive to low concentrations of metals and is therefore a suitable bioindicator for evaluating toxic metal pollution in lentic aquatic ecosystems in South America.

\subsection{Chemical analysis and biological data corroborate Vossoroca Reservoir as impaired by anthropogenic activities}

It is understood that the Vossoroca Reservoir is impaired by human activity. Therefore, more attention should be given to this ecosystem, and regular and long-term monitoring of the lake and its fish species is essential. The results of this study show that even within the legal limits, arsenic and some metals can still have negative effects on the aquatic life. This information can assist authorities in decision-making processes in their attempts to protect local wildlife and improve water quality; ideally, this information will ultimately make the water viable for human use.

This conclusion was possible only because of the combination of analyses: metal concentrations in the water, in the sediment and in different fish tissues, and data on the biological effects on fish.

\section{CONCLUSIONS}

This is the first study conducted in the Vossoroca Reservoir in Brazil, and although the reservoir is in an environmental protection area, concentrations of $\mathrm{Cd}$ in water, and levels of $\mathrm{Cr}, \mathrm{Cu}, \mathrm{Ni}, \mathrm{Cd}$ and $\mathrm{As}$ in sediment and $\mathrm{Pb}$ in fish muscle were above the limits established by Brazilian law and some international parameters. It must therefore be noted that chronic exposure to the conditions found in the reservoir modifies the basic morphology of target 
organs, such as the liver and gills, as was seen in G. brasiliensis. Those alterations may impair the proper functioning of these tissues.

The current study also offers important information on the response to stressors that a suitable bioindicator and a native fish species, Geophagus brasiliensis, may exhibit as a result of chronic exposure to metal contaminants. Thus, only through a careful review of the current Brazilian legislature on legal thresholds for toxicants can the water in this reservoir become safe, both for the local biota and for human consumption. Legal limits that are more consistent with international standards and that are then enforced in the country will result in a larger variety of potable water sources.

\section{REFERENCES}

AGÊNCIA NACIONAL DE VIGILÂNCIA SANITÁRIA (Brasil). Decreto $n^{0}$ 55.871, de 26 de março de 1965. Diário Oficial [da] União, 09 abr. 1965.

AGÊNCIA NACIONAL DE VIGILÂNCIA SANITÁRIA (Brasil). Portaria $n^{\circ}$ 685, de 27 de agosto de 1998. Diário Oficial [da] União, 28 ago. 1998.

AGIUS C.; ROBERTS, R. J. Melanomacrophage centres and their role in fish pathology. Journal of Fish Diseases, v. 26, n. 9, p. 499-509, 2003. http://dx.doi.org/10.1046/j.13652761.2003.00485.x

AGTAS, S.; GEY, H.; GUL, S. Concentration of heavy metals in water and chub, Leuciscus cephalus (Linn.) from the river Yildiz, Turkey. Journal of Environmental Biology, v. 28, n. 4, p. 845-849, 2007.

AKAISHI, F. M.; SILVA DE ASSIS, H. C.; JAKOBI, S. C. G.; EIRAS-STOFELLA, D. R.; ST-JEAN, S. D.; COURTENAY, S. C. et al. Morphological and neurotoxicological findings in tropical freshwater fish (Astyanax sp.) after waterborne and acute exposure to water soluble fraction (WSF) of crude oil. Archives of Environmental Contamination and Toxicology, v. 46, n.2, p. 244-253, 2004. http://dx.doi.org/10.1007/s00244-003$2260-1$

ALLOWAY, B. J. Heavy metals in soils. Trace metals and metalloids in soils and their bioavailability. Netherlands: Springer, 2013. p. 587.

ANDERSON, R. A. Chromium as an Essential Nutrient for Humans. Regulatory Toxicology $\begin{array}{lllllll}\text { and Pharmacology, } & \text { v. 26, n. 1, p. S35-S41, }\end{array}$ http://dx.doi.org/10.1006/rtph.1997.1136

AU, D. W. T. The application of histo-cytopathological biomarkers in marine pollution monitoring: a review. Marine Pollution Bulletin, v. 48, n. 9-10, p. 817-834, 2004. http://dx.doi.org/10.1016/j.marpolbul.2004.02.032

AYAS, Z.; EKMEKCI, G.; OZMEN, M.; YERLI, S. V. Histopathological changes in the livers and kidneys of fish in Sariyar Reservoir, Turkey. Environmental Toxicology and $\begin{array}{llllll}\text { Pharmacology, } & \text { v. } 23, \quad \text { n. } & 2, & \text { p.242-249, }\end{array}$ http://dx.doi.org/10.1016/j.etap.2006.11.003 
BALAMURUGAN, S.; DEIVASIGMANI, B.; KUMARAN, S.; SAKTHIVEL, M.; RAJSEKAR, T.; PRIYADHARSINI, P. Melanomacrophage centers aggregation in P. lineatus spleen as bioindicator of environmental change. Asian Pacific Journal of Tropical Disease, v. 2, p. 635-S638, 2012. http://dx.doi.org/10.1016/S22221808(12)60235-7

BEIJER, K.; JERNELOV, A. Sources, transport and transformation of metals in the environment. In: NORDBERG, G. F.; FOWLER, B. A.; NORDBERG, M.; FRIBERG, L. T. (Eds.). Handbook on the toxicology of metals: general aspects. $2^{\text {nd }}$ ed. Amsterdam: Elsevier, 1986. p. 68-74.

BENINCÁ, C.; RAMSDORF, W.; VICARI, T.; OLIVEIRA RIBEIRO, C. A.; ALMEIDA, M. I.; SILVA DE ASSIS, H. C. Chronic genetic damages in Geophagus brasiliensis exposed to anthropic impact in estuarine lakes at Santa Catarina coast-southern of Brazil. Environmental Monitoring and Assessment, v. 184, n. 4, p. 2045-56, 2012. http://dx.doi.org/10.1007/s10661-011-2098-3

BERNET, D.; SCHIMIDT, H.; MEIER, W.; BURKHARDT-HOLM, P.; WAHILI, T. Histopathology in fish: proposal for a protocol to assess aquatic pollution. Journal of Fish Diseases, v. 22, n. 1, p. 25-34, 1999. http://dx.doi.org/10.1046/j.13652761.1999.00134.x

BESIROVIC, H.; ALI, A.; PRASOVI, S.; DROMMER, W. Histopathological Effects of Chronic Exposure to Cadmium and Zinc on Kidneys and Gills of Brown Trout (Salmo trutta). Turkish Journal of Fisheries and Aquatic Sciences, v.10, n. 2, p. 255-262, 2010. http://dx.doi.org/10.4194/trjfas.2010.0214

BIAGIANTI-RISBOURG, S.; VERNET, G.; BOULEKBACHE, H. Ultrastructural response of the liver of rainbow trout, Oncorhynchus mykiss, sac-fry exposed to acetone. Chemosphere, v. 36, n. 9, p. 1911-1922, 1998. http://dx.doi.org/10.1016/S00456535(97)10076-5

BIAGINI, F. R.; OLIVEIRA DAVID, J. A.; FONTANETTI, C. S. The use of histological, histochemical and ultramorphological techniques to detect gill alterations in Oreochromis niloticus reared in treated polluted waters. Micron, v. 40, n. 8, p. 839-844, 2009. http://dx.doi.org/10.1016/j.micron.2009.06.010

BLANCO, M. V.; CATTONI, D. I.; CARRIQUIRIBORDE, P.; GRIGERA, J. R.; CHARA, O. Kinetics of bioaccumulation of heavy metals in Odontesthes onariensis is explained by a single and common mechanism. Ecological Modelling, v. 274, p. 50-56, 2014. http://dx.doi.org/10.1016/j.ecolmodel.2013.12.002

BREMBATTI, K. Mananciais distantes vão matar a sede de 4 milhões de pessoas. Gazeta do Povo, March 10, 2014. Available in: https://goo.gl/3GxIRm Access in: 20 June 2014.

CALZA, C.; ANJOS, M. J.; CASTRO, C.R.F.; BARROSO, R.C.; ARAUJO, F G.; LOPES, R.T. Evaluation of heavy metals levels in the Paraíba do Sul River by SRTXRF in muscle, gonads and gills of Geophagus brasiliensis. Radiation Physics and Chemistry, United Kingdom, v. 71, p. 787-788, 2004.

CAMARGO, M. M. P.; FERNANDES, M. N.; MARTINEZ, C. B. R. How aluminum exposure promotes osmoregulatory disturbances in the neotropical freshwater fish Prochilus lineatus. Aquatic Toxicology, v. 94, n. 1, p. 40-46, 2009. http://dx.doi. org/10.1016/j.aquatox.2009.05.017 
CAMARGO, M. M. P.; MARTINEZ, C. B. R. Histopathology of gills, kidney and liver of a neotropical fish caged in an urban stream. Neotropical Ichthyology, v. 5, n. 3, p. 327336, 2007. http://dx.doi.org/0.1590/S1679-62252007000300013

CANADIAN ENVIRONMENTAL QUALITY GUIDELINES. Summary tables. Available in: http://st-ts.ccme.ca/. Access in: 24 May 2014.

CASTRO-GONZÁLEZ, M. I.; MÉNDEZ-ARMENTA, M. Heavy metals: Implications associated to fish consumption. Environmental Toxicology and Pharmacology, v. 26, n. 3, p. 263-271, 2008. http://dx.doi.org/10.1016/j.etap.2008.06.001

CLEMENTE, Z.; BUSATO, R. H.; OLIVEIRA RIBEIRO, C. A.; CESTARI, M. M.; RAMSDORF, W. A.; MAGALHÃES, V. F. et al. Analyses of paralytic shellfish toxins and biomarkers in a southern Brazilian reservoir. Toxicon, v. 55, n. 2-3, p. 396-406, 2010. http://dx.doi.org/10.1016/j.toxicon.2009.09.003

COMISSÃO NACIONAL DO MEIO AMBIENTE (Brasil). Resolução n ${ }^{0} 454$ de 01 de novembro de 2012. Diário Oficial [da] União, 08 nov. 2012.

COMISSÃO NACIONAL DO MEIO AMBIENTE (Brasil). Resolução no 357 de 17 de mar. 2005. Diário Oficial [da] União, n. 53, seção 1, p. 58-63, 18 mar. 2005.

COSTA, P. M.; DINIZ, M. S.; CAIEIRO, S.; LOBO, J.; MARTINS, M.; FERREIRA, A. M. et al. Histological biomarkers in liver and gills of juvenile Solea senegalensis exposed to contaminated estuarine sediments: a weighted indices approach. Aquatic Toxicology, v. 92, n.3, p. 202-212, 2009. http://dx.doi.org/10.1016/j.aquatox.2008.12.009

DEMIRAK, A.; YILMAZ, F.; LEVENT TUNA, A.; OZDEMIR, N. Heavy metals in water, sediment and tissues of Leuciscus cephalus from a stream in southwestern Turkey. Chemosphere, v. 63, n. 9, p. 1451-1458, 2006.

http://dx.doi.org/10.1016/j.chemosphere.2005.09.033

EUROPEAN COMMISSION. Regulation n. 1881/2006 of 19 December 2006. Setting maximum levels for certain contaminants in foodstuffs (text with EEA relevance). Official Journal of European Union, v. 49, L 364, 2006.

FERREIRA, A. P.; HORTA, M. A. P.; CUNHA, C. L. N. Assessment of heavy metal concentrations in sediment, water and organs of Nycticorax (Black-crowned Night Heron) in Sepetiba Bay, Rio de Janeiro. Brazilian Journal of Integrated Coastal Zone Manage, v. 10, p. 229-241, 2010.

GOMIERO, L. M.; BRAGA, F. M. S. Feeding habits of the ichthyofauna in a protected area in the state of São Paulo, southeastern Brazil. Biota Neotropica, v. 8, n.1, p. 41-47, 2008. http://dx.doi.org/10.1590/S1676-06032008000100004

HANSEN, B. H.; ROMMA, S.; GARMO, Ø. A.; PEDERSEN, S. A.; OLSKIV, P. A.; ANDERSEN, R. A. Induction and activity of oxidative stress-related proteins during waterborne $\mathrm{Cd} / \mathrm{Zn}$-exposure in brown trout (Salmo trutta). Chemosphere, v. 67, n. 11, p. 2241-2249, 2007. http://dx.doi.org/10.1016/j.chemosphere.2006.12.048 
HAUSER-DAVIS, R.; OLIVEIRA, T. F.; SILVEIRA, A. M.; SILVA, T. B.; ZIOLLI, R. L. Case study: Comparing the use of nonlinear discriminating analysis and Artificial Neural Networks in the classification of three fish species: acaras (Geophagus brasiliensis), tilapias (Tilapia rendalli) and mullets (Mugil liza). Ecological Informatics, v. 5, n. 6, p. 474-478, 2010. http://dx.doi.org/10.1016/j.ecoinf.2010.08.002

HINTON, D. E.; SEGNER, H.; AU, D. W.; KULLMAN, S. W.; HARDMAN, R. C. Liver toxicity. In: DI GIULIO, R. T.; HINTON, D. E. (ED.) Toxicology of fishes. USA: CRC Press, 2008. p. 327-400.

INSTITUTO AMBIENTAL DO PARANÁ - IAP. Monitoramento da qualidade dos reservatórios do estado do Paraná, no período de 2005 a 2008. 2009. Available in: http://www.iap.pr.gov.br/arquivos/File/boletins/RELATORIO_AGUA/relatorio_RESE RVATORIOS_2005_2008.pdf. Access in: 16 Aug. 2016.

JAESCHEKE, H.; GORES, G. J.; CEDERBAUM, A. I.; HINSON, J. A.; PESSAYRE, D.; LEMASTERS, J.J. Mechanisms of hepatotoxicity. Toxicological Sciences, v. 65, p. 166176, 2002. http://dx.doi.org/10.1093/toxsci/65.2.166

JAISHANKAR, M.; TSETEN, T.; ANBALAGAN, N.; MATHEW, B.B.; BEEREGOWDA, K.N. Toxicity, mechanism and health effects of some heavy metals. Interdisciplinary Toxicology, v. 7, n. 2, p. 60-72, 2014.

JEZIERSKA, B.; WITESKA, M. The metal uptake and accumulation in fish living in polluted water. In: ALLEN, H. E.; TWARDOWSKA, I.; HÄGGBLOM, M. M.; STEFANIAK, S. Viable methods of soil and water pollution monitoring, protection and remediation, Amsterdam: Springer, 2006. p. 107-114.

KARADEDE, H.; OYMAK, S. A.; ÜNLU, E. Heavy metals in mullet, Liza abu, and catfish, Siluris triostegus, from the Atatürk Dam Lake (Euphrates), Turkey. Environment International, v. 30, n. 2, p. 183-188, 2004. http://dx.doi.org/10.1016/S01604120(03)00169-7

LALL, S. P. The Minerals. In: HALVER, J. (Ed.). Fish nutrition. San Diego: Elsevier Academic press, 2002. p. 259-308.

LAU, S.; MOHAMMED, M. A.; YEN, T. C.; SUUT, S. Accumulation of heavy metals in fresh water molluscs. Science of the Total Environment, v. 214, p. 113-121, 1998. http://dx.doi.org/10.1016/S0048-9697(98)00058-8

LI, L.; ZHENG, B.; LIU, L. Biomonitoring and bioindicators used for river ecosystems: Definitions, approaches and trends. Procedia Environmental Sciences, v. 2, p. 15101524, 2010. http://dx.doi.org/10.1016/j.proenv.2010.10.164

LIU, X. J.; LUO, Z.; LI, C. H.; XIONG, B. X.; ZHAO, Y. H.; LI, X. D. Antioxidant responses, hepatic intermediary metabolism, histology and ultrastructure in Synechogobius hasta exposed to waterborne cadmium. Ecotoxicology and Environmental Safety, v. 74, n. 5, p. 1156-1163, 2011. http://dx.doi.org/10.1016/j.ecoenv.2011.02.015

LOWE-MCCONNELL, R. H. Estudos ecológicos de comunidades de peixes tropicais. São Paulo: Editora da Universidade de São Paulo, 1999. p. 534.

MACDONALD, D. D.; INGERSOLL, C. G.; BERGER, T. A. Development and evaluation of consensus-based sediment quality guidelines for freshwater ecosystems. Archives of Environmental Contamination and Toxicology, v. 39, n. 1, p. 20-31, 2000. http://dx.doi.org/10.1002/etc.5620190524 
MACEDA-VEIGA, A.; MONROY, M.; DE SOSTA, A. Metal bioaccumulation in the Mediterranean barbel (Barbus meridionalis) in a Mediterranean river receiving effluents from urban and industrial wastewater treatment plants. Ecotoxicology and Environmental Safety, v. 76, n. 2, p. 93-101, 2012.http://dx.doi.org/10.1016/j. ecoenv.2011.09.013

MAZZONI, R.; IGLESIAS-RIOS, R. Environmentally related life history variations in Geophagus brasiliensis. Journal of Fish Biology, v. 6, p. 1606-1618, 2002. http://dx.doi.org/10.1111/j.1095-8649.2002.tb02501.x

MELA, M.; GUILOSKI, I. C.; DORIA, H. B.; RABITTO, I. S.; SILVA, C. A.; MARASCHI, A. C. et al. Risks of waterborne copper exposure to a cultivated freshwater Neotropical catfish Rhamdia quelen. Ecotoxicology and Environmental Safety, v. 88, p. 108-116, 2013. http://dx.doi.org/10.1016/j.ecoenv.2012.11.002

MENDIL, D.; ULUOZLU, Ö. D. Determination of trace metal levels in sediment and five fish species from lakes in Tokat, Turkey. Food Chemistry, v. 101, n. 2, p. 739-745, 2007. http://dx.doi.org/10.1016/j.foodchem.2006.01.050

MORAES, M. F. P. G.; BARBOLA, I. F.; DUBOC, L. F. Feeding habits and morphometry of digestive tracts of Geophagus brasiliensis (Osteichthyes, Cichlidae), in a lagoon of high Tibagi River, Paraná State, Brazil. Ciências Biológicas e da Saúde, v. 10, p. 37-45, 2004.

MOREIRA, C. B.; RODRIGUES, R. V.; ROMANO, L. A.; GUSMÃO, E. P.; SEYFFERT, B. H.; SAMPAIO, L. A. et al. Genotoxicity and histological alterations in grey mullet Mugil liza exposed to petroleum water-soluble fraction (PWSF). Environmental Science and Pollution Research International, v. 21, n. 8, p. 5565-5574, 2014. http://dx.doi.org/10.1007/s11356-013-2440-0

OSÓRIO, F. H. T.; SILVA, L. F. O.; PIANCINI, L. D. S.; AZEVEDO, A. C. B.; LIEBEL, S.; YAMAMOTO, F. Y. et al. Water quality assessment of the Tubarão River through chemical analysis and biomarkers in the Neotropical fish Geophagus brasiliensis. Environmental Science and Pollution Research International, v. 21, n. 15, p. 9145 60, 2013. http://dx.doi.org/10.1007/s11356-013-1512-5

PANDEY, S.; PARVEZ, S.; ANSARI, R. A.; ALI, M.; KAUR, M.; HAYAT, F. et al. Effects of exposure to multiple trace metals on biochemical, histological and ultrastructural features of gills of a freshwater fish, Channa punctata Bloch. Chemico-biological Interactions, v. 174, p. 183-192, 2008. http://dx.doi.org/10.1016/j.cbi.2008.05.014

PAPAGIANNIS, I.; KAGALOU, I.; LEONARDOS, J.; PETRIDIS, D.; KALFAKOU, V. Copper and zinc in four freshwater fish species from Lake Pamvotis (Greece). Environment International, v. 30, n. 3, p. 357-362, 2004. http://dx.doi. org/10.1016/j.envint.2003.08.002

PARAGUASSÚ, A. R.; ALVES, D. R.; LUQUE, J. L. Metazoários parasitos do acará Geophagus brasiliensis (Quoy e Gaimard, 1824) (Osteichthyes: Cichlidae) do Reservatorio de Lajes, Estado do Rio de Janeiro, Brasil. Revista Brasileira de Parasitologia Veterinária, v. 14, p. 35-39, 2005.

PAWERT, M.; MULLER, E.; TRIEBSKOR, N. R. Ultrastructural changes in fish gills as biomarker to assess small stream pollution. Tissue and Cell, v. 30, p. 617-626, 1998.

Rev. Ambient. Água vol. 12 n. 4 Taubaté - Jul. / Aug. 2017 
POURANG, N.; TANABE, S.; REZVANI, S.; DENNIS, J. Trace elements accumulation in edible tissues of five sturgeon species from the Caspian Sea. Environmental Monitoring and Assessment, v. 100, n. 1-3, p. 89-108, 2005. http://dx.doi.org/10.1007/s10661-0057054-7

PYLE, G. G.; RAJOTTE, J. W. COUTURE, P. Effects of industrial metals on wild fish populations along a metal contamination gradient. Ecotoxicology and Environmental Safety, v. 61, n. 3, p. 287-312, 2005. http://dx.doi.org/10.1016/j.ecoenv.2004.09.003

RABITTO, I. S.; ALVES COSTA, J. R. M.; SILVA DE ASSIS, H. C.; PELlETIER, E.; AKAISHI, F. M.; ANJOS, A. et al. Effects of dietary $\mathrm{Pb}(\mathrm{II})$ and tributyltin on neotropical fish, Hoplias malabaricus: histopatological and biochemical findings. Ecotoxicology and Environmental Safety, v. 60, n. 2, p. 147-156, 2005. http://dx.doi.org/10.1016/j.ecoenv.2004.03.002

RASHED, M. N. Monitoring of environmental heavy metals in fish from Nasser Lake. Environment International, v. 27, n. 1, p. 27-33, 2001. http://dx.doi.org/ $10.1016 / \mathrm{S} 0160-4120(01) 00050-2$

RUAS, C. B. G.; CARVAlHO, C. D. S.; ARAÚJO, H. S. S.; ESPÍNDOLA, E. L. G.; FERNANDES, M.N. Oxidative stress biomarkers of exposure in the blood of cichlid species from a metal-contaminated river. Ecotoxicology and Environmental Safety, v. 71, n. 1, p. 86-93, 2008. http://dx.doi.org/10.1016/j.ecoenv.2007.08.018

SAFAHIEH, A.; HEDAYATI, A.; SAVARI, A.; MOVAHEDINIA, A. Effect of sub-lethal dose of mercury toxicity on liver cells and tissue of yellowfin seabream. Toxicology and Industrial Health, v. 28, p. 583-592, 2011.

http://dx.doi.org/10.1177/0748233711416951

SUZUKI, H. I; AGOSTINHO, A. A. Reprodução de peixes do reservatório de Segredo. In: GOMES, L. C.; AGOSTINHO, A. A. Reservatório de Segredo: bases ecológicas para o manejo. Maringá: EDUEM, 1997. p. 163-182.

THOMAS, R. L. A protocol for the selection of process-oriented remedial options to control in situ sediment contaminants. Hydrobiologia, v 149, n. 1, p. 247-258, 1987. http://dx.doi.org/10.1007/BF00048664

UNITED STATES. Environmental Protection Agency. Office of Water. Methods for collection, storage and manipulation of sediments for chemical and toxicological analyses: technical manual. EPA 823-B-01-002. 2001. Available in: http://water.epa.gov/polwaste/ sediments/cs/upload/toc.pdf . Access in: 12 Mach 2014.

UNITED STATES. Environmental Protection Agency. Office of Water. Acid Digestion of Waters for Total Recoverable or Dissolved Metals for Analysis by FLAA or ICP Spectroscopy. Method EPA-3005A. 1992. Available in: http://www.epa.gov/osw/hazard/test-methods/sw846/pdfs/3005a.pdf. Access in: 12 March 2014.

UNITED STATES. Environmental Protection Agency. Office of Water. Acid Digestion of Sediments, Sludges and Soils. Method EPA-3050B. 1996. Available in: http://www.epa.gov/wastes/hazard/testmethods/sw846/pdfs/3050b.pdf. Access in: 12 March 2014.

VALKO, M.; MORRIS, H.; CRONIN, M. T. D. Metals, toxicity and oxidative stress. Current Topics in Medicinal Chemistry, v. 12, p. 1161-1208, 2005. 
VAN DYK, J. C.; MARCHAND, M. J.; SMIT, N. J.; PIETERSE, G. M. A. Histology-based fish health assessment of four commercially and ecologically important species from the Okavango Delta panhandle, Botswana. African Journal of Aquatic Science, v. 34, n. 3, p. 273-282, 2009. http://dx.doi.org/10.2989/AJAS.2009.34.3.9.985

VAN LEEUWEN, C. J.; VERMEIRE, T. G. Risk assessment of chemicals: An introduction. $2^{\text {nd }}$ ed. The Netherlands: Springer, 2007. 686 p.

WILHELM FILHO, D.; TORRES, M. A.; TRIBESS, T. B.; PEDROSA, R. C.; SOARES, C. $\mathrm{H}$. Influence of season and pollution on the antioxidant defenses of the cichlid fish acará (Geophagus brasiliensis). Brazilian Journal of Medical and Biological Research, v. 34, n. 6, p. 719-726, 2001.

WEI, Y.; ZHANG, J.; ZHANG, D.; TU, T.; LUO, L. Metal concentrations in various fish organs of different fish species from Poyang Lake, China. Ecotoxicology and Environmental Safety, v. 104, p. 182-188, 2014. http://dx.doi.org/10. 1016/j.ecoenv.2014.03.001

WOLF, J. C.; WOLFE, M. J. A brief overview of non-neoplastic hepatic toxicity in fish. Toxicologic Pathology, v. 33, n. 1, p. 75-85, 2005. http://dx.doi.org/10.1080/ 01926230590890187 